\title{
US-led TPPA and Its Implication on China Positions in Southeast Asian Regionalism
}

\section{Mohamed Aslam*}

Abstract: $\quad$ Prior to the development of ASEAN Plus Three, ASEAN was the main architecture integrating countries in Southeast Asia. The organization was able to develop a closer economic cooperation with China, Japan and South Korea. However, China and Japan competing and attempting to "dictate" each other and what regionalism should be and whom it benefits. Small states such as the members of ASEAN and those skeptical of China's motives in Southeast Asia including China's territorial claims to the South China Sea would cling to the US. Political and economic development over the past 10 years reveal that the close allies of the United States of America (USA) such as Japan, South Korea, Singapore, Australia and New Zealand, were unable to "limit" China's growing domination in the Southeast Asian region. The TPPA that was allegedly "hijacked" and led by the US since November 2009, was believed as a counter measure to check China's growing power in Southeast Asia. If the TPPA is not meant to limit China's presence in the region, the agreement would function as a pathfinder for the Free Trade Area of the Asia-Pacific. This paper attempts to answer (i) what is the motive of the US government involvement in TPPA, (ii) what the posible implication of TPPA to China (iii) what would happen to China's role in the region, and (iv) what insurance actions developed by China.

Key Words: $\quad$ Free trade area, trans-pacific partnerships agreement, United States of America, China, ASEAN and Southeast Asia

\footnotetext{
*Dr, University of Malaya, Faculty of Economics and Administration, maslam@um.edu.my
} 


\section{Introduction}

Since the early 1990s, ASEAN in fact occupies a core position in the economic integration of Southeast Asia. Actually ASEAN was the main architecture and a driving force in integrating all countries in Southeast Asia into a form of bilateral economic partnership, i.e., free trade area. With the development of the East Asia Economic Caucus (EAEC), ASEAN+3 and the East Asia Summit initiated by ASEAN. These regional arrangements expanded and enhanced ASEAN's role, it relevance and centrality in Southeast Asia. However, ASEAN's centrality is now challenged by many new and overlapping economic cooperation arrangements in the region including the TPPA. ASEAN aims to preserve its centrality to economic co-operation within Southeast and East Asia may fall a part. The Trans-Pacific Partnership agreement which steered by the United States of America government is regarded as a major threat to ASEAN role.

Since the Open Economic Policy (OEP) announced in 1978, China knew that the country may face hurdles in developing its economy because the open door policy will generate uneasiness among her neighbors particularly ASEAN countries. The OEP may deliver a negative economic and security impact to those countries. To remove the unwanted speculation and a negative perception of their economic policies, China actively established and strenghthend economic as well as political relations with countries in the region such as creating bilateral economic relationships. ASEAN's invitation to China to join the East Asia Economic Caucus (EAEC) for instance was a first step and acts as a catalyst to the Chinese government in building a good relationship with her neighbors. Thus, economic relations between China and ASEAN developed and enhanced at a rapid pace. ASEAN and China signed FTA agreements (ACFTA) in November 2002. ACFTA covers agreements on the goods sector that was signed in November 2002. Both sides also signed agreements on investment liberalization in 2005 and agreements on services sector liberalization in 2008. Bilateral trade between ASEAN and China has increased more than 3 fold since the 1990s. In addition, since 1995 China trade with Japan, South Korea and Taiwan has soared at rapid pace. The remarkable economic expansion of China has integrated economically the Northeast and Southeast Asia countries. In 2000, ASEAN, China, Japan and South Korea agreed to develop the Chiang Mai Initiative (CMI), a regional currency swap to alleviate future currency crises ${ }^{1}$. The CMI was proposed by China followed by a revised version via the Asian Monetary Fund proposed by Japan during the Asian financial crisis. The role of China in the CMI enhanced China's role in the region while the US role since that time has been marginalized. More overover, China had joined ASEAN Regional Forum and Six Party Talks. China involvement in these multilateral arrangements in some ways certainly had install uneasiness to the US government and challenging the US hegemony in the Asia Pacific and Southeast Asia regions. According to Breslin and Shambaugh, the American suspects that China has been using the mentioned multilateral means not as an order-building process but also as an instrument to isolate the United States in region ${ }^{2}$.

Before the establishment of ACFTA, the US governmnet is less emphasize and strenghten economic and political relationship in Southeast Asia. When China economic and political engagement with Southeast Asia countries accelarating at a considerable degree which in future will influence the US role in Asia Pacific and Southeast Asia, the US governmnet slowly refocusing to Southeast Asia. Therefore, to ensure the relevance of the US in Southeast Asia, the "only immediate available" solution was to join the P4-TPP. The involvement of the US and then to lead the "new" TPP (hereafter TPPA) appears to be an attempt to re-consolidate its position and significance in Southeast Asia. The US government realizes that the country's economic health in the $21^{\text {st }}$ century and beyond will depend on a stable and vibrant Asian economy ${ }^{3}$. Since 1945, the U.S. has supported the security, stability and economic growth in the Asia-Pacific region, eventhough not extensively, however this would be an added advantage. This history is reflected in diplomatic, economic and military relationships with various countries in Asia. The TPPA is merely not only to lessen ASEAN role but also to check and rebalance China economic and political influence in the region. As what I believes, the TPPA-led by the US is actually has a triple strategies, to reduce ASEAN role, to reduce China presence and to increase US influence in the region. 
Singapore, Chile and New Zealand were the first three countries to engage in closer economic cooperation under the group known as the Pacific Three Closer Economic Partnership (P3-CEP) in 2002. When Brunei joined the group in 2005 the group was named as the "P4" or Trans-Pacific Strategic Economic Partnership (TPP). The four countries signed the agreement on June 5, 2005. The agreement entered into force on May 28, 2006. This TPP agreement ${ }^{4}$ branded $^{2}$ as a new standard for a trade and economic partnership agreement that comprises wide areas of economic and non-economic issues compared to many "normal" FTA agreements such as the agreement between ASEAN and China, ASEAN and South Korea and ASEAN-Japan covering market access (goods mobility), investment liberalization and liberalization of the services sector. The P4 countries are small countries in terms of market size and external trade growth. Therefore this agreement may not increase intra-trade and develop solid economic integration among P4 countries $^{5}$. Other developing countries including other members of ASEAN are not keen to join the group primarily due to the inability of these countries to agree to certain provisions and issues that were negotiated in TPP. In other words, they are not ready for extensive economic liberalization as impnated in TPP agreement. Also the prospects of P4-TPP to stimulate intratrade, was assumed as not promising enough to other members of ASEAN. The intra-trade of P4TPP is relatively smaller than the intra-trade of the ASEAN Free Trade Area (AFTA). Major trade partners to P4-TPP members are United States, Japan and China, and these three countries are also major trade partners to ASEAN members.

Another notable reason for the reluctance to join is that none of the countries in the group is strong enough politically and economically to lead the bloc. Also there is no an anchor country to lead significantly the group. The Australian government joined the P4-TPP in 2006 but the country was unable to lead the bloc because the government lacks political influence in the region. The government's role in regionalism in Asia-Pacific and in Southeast Asia is rather weak. ASEAN and other Southeast Asian countries regard Australia and New Zealand as "nonAsian". Countries in these regions assume Australia and New Zealand to be "Western" and major allies to the United States of America. In fact, Australia needs a strong country such as the USA or Japan in any regional economic arrangement. For example, the US and Japan suggested the Asia Pacific Economic Cooperation (APEC) in 1989. The formation and realization of APEC was due to huge backing by the American and Japanese governments. Therefore, the bloc seems to not be attractive to other countries in the Asia Pacific region, nor in Southeast Asia nor to other members of ASEAN. Nevertheless, the TPP agreement itself may have drawn the attention of US policymakers because the agreement covers wide areas of economic and businesses interests compared to other FTA arrangements in Asia. American politicians particularly President Barack Obama and his inner circle, believed that the P4-TPP agreement could be used, modified and expanded to be re-labeled as a "new" TPP agreement, hereafter TPPA, and then promoted and marketed to other countries in Southeast Asia and the Asia Pacific region. The Obama administration team aggressively promotes the TPPA mainly to fulfill US interests rather than the interests of its partners.

\section{The United States of America and the TPPA.}

The US government joined the TPP on November 14, 2009 and I assume the government allegedly "hijacked" and then eventually led the bloc thereafter. Before the US joined the TPP group, the US already had Free Trade Agreements (FTA) with P4-TPP members such as Singapore and Chile. President Obama notified Congress of his intention to negotiate with the existing TPP members on September 22, 2008, and with other potential members Peru and Vietnam on December 30, 2008. On November 14, 2009, President Obama made a committment on behalf of the United States to engage with the TPP countries, as he mentioned, "with the goal of shaping a regional agreement that will have broad-based membership and the high standards worthy of a 21st century trade agreement". Various people called the TPPA a "gold standard" agreement. Senator Charles Grassley, ranking member of the Committee on Finance, welcomed the United States joining the group. Grassley said, "It's in our national interest to strengthen our economic relations with the Trans-Pacific region. Negotiation of this agreement will help further 
that effort. And it may pave the way to a broader regional trade agreement in the future. If we want to have any influence over that process, we need to get involved. We can't advance our economic interests if we're not at the table", ${ }^{\text {, }}$. While in Tokyo during November 2009, President Obama also stated that the growth of multilateral organizations can advance the security and prosperity of this region. "As an Asia Pacific nation, the United States expects to be involved in the discussions that shape the future of this region and to participate fully in appropriate organizations as they are established and evolve", ${ }^{\text {. }}$

The Obama administration has turned the TPP into a tool to pursue America's main agenda in international trade and political issues. The P4-TPP agreement was re-drafted, modified and extended the coverage of economic and business related areas. This new TPP agreement, hereafter called TPPA. I assumed whatever subjects negotiated under Doha Round were brought into this new agreement. Some economists stated that the TPPA agreements based on US-Korea FTA which was signed on June $30,2007^{9}$. The agreement is supposed to fulfill American economic interests rather than the interests of current and prospective members of TPPA. The government treated the TPPA as a stepping-stone to greater involvement in Southeast Asian and Asia Pacific economic matters as well as in politics and security more seriously and deeply ${ }^{10}$.

The first round of TPPA negotiation led by the US started in March 2010 with members of P4, the US, Australia, Peru, Vietnam, and Malaysia. Before 2011 the TPPA had nine participants with a small number of countries in the group that cannot achieve a sufficient scale of economy. From 2013 onwards there are 12 Trans-Pacific Partnership countries: Australia, Brunei Darussalam, Canada, Chile, Japan, Malaysia, Mexico, New Zealand, Peru, Singapore, the United States, and Vietnam. The US government is the prime mover of the TPPA agreement. The TPPA includes a wide range of economic and non-economic issues as FTA agreements signed between the US and its partners ${ }^{11}$. The agreement follows a US government regional economic cooperation architecture/FTA standard. The TPPA is a comprehensive agreement covering market access, non-agriculture market access (NAMA), agriculture, NTBs, services (fully liberal), IPR, pharmaceutical, $\mathrm{T} \& \mathrm{C}$, investment- complete liberalization, safeguard mechanisms, transparency, e-commerce, government procurement, removal of red-tape hurdling trade and investments, dispute settlements, trade and development, trade and technology transfer, trade facilitation, trade and environment, as well as another which I suspect to be trade and labor ${ }^{12}$ and liberal Rules of Origin (ROO). This agreement framework seems to be a mini multilateral trade negotiation. The above-mentioned subjects covered by the agreement are speculative. The actual draft of the agreement remains unknown to the public until this day.

Negotiations for the Trans-Pacific Strategic Economic Partnership (TPPA) were anticipated to conclude in 2010 before the Asia Pacific Economic Cooperation (APEC) leaders' meeting in November 2011. After 21 rounds, the 12 countries have made some significant progress but the agreement is yet to be agreed upon. The lack of consensus between members on some provisions of the Agreement has extended the deadline. Finalizing the agreement has been delayed since August 2013 mainly due to Japan. The unwillingness of the Japanese government to open her agriculture sector and to remove non-tariff barriers stalled negotiations. It seems that Japan may be re-drafting the TPPA. Until May 2014 there have been 21 rounds of negotiations of the TPPA but there is no solid indicator that the agreement will be finalized in near future.

Since its involvement in the TPPA, the US has become quite aggressive. It seems that the US plans to finalize the agreement as scheduled or before President Obama's term is over in 2016. If the TPPA materializes, it will be a legacy of the Obama administration for the American people. The agreement was restructured as mentioned and definitely favors the US economy in the long-term. Through this agreement, the Obama Administration is seeking to boost U.S. economic growth and support the creation and retention of high-quality American jobs by increasing exports to a region that includes some of the world's most robust economies and that represents more than 40 percent of global trade. The Obama Administration is working in close partnership with Congress and with a wide range of stakeholders to conclude a strong agreement that addresses issues that U.S. businesses and workers face in the 21 st century. 


\section{Why US join the TPPA. Domestic and China factors}

The New Zealand government invited the US to participate in the P4-TPP in $2005^{13}$. However, the US government with George Bush Jr. as President, rejected full participation of the US in the TPP. In February 2008, former President Bush announced that the US would join the P-4 negotiations limited to the areas of financial services and investment. In March 2008, the US participated in P-4 negotiations on certain economic areas the US was interested in including financial services and investment. On September 22, 2008, former US Trade Representative Susan C Schwab announced that the US would begin negotiations with the P4 countries to join the TPP starting with the first round of talks in early 2009. The big question is why was the US so late in joining the TPP if the bloc would be able to produce significant benefits to the US economy? Reasons given by the US government as stated by Senator and Ambassador Susan C Schwab, the former US Trade Representative from 2006 to 2009, is that the US was hoping that the Doha Round would be concluded by 2008 or 2009, but that this expectation flattened. The TPPA seem to be the cornerstone of the Obama Administration's economic policy in the AsiaPacific region.

Besides the reason mentioned by Ms Susan above, there are a few possible reasons why the US finally joined the TPP. The first reason as stated by US Trade Representative Schwab was the possible collapse of the Doha Round. There was speculation that the Doha Round was a tool for the American government to build a new "administered trade" in the world economy under the auspices of the World Trade Organization (WTO). There was unhappiness among developing countries with regard to many issues, provisions and modalities of the Doha agreement. Less commitment was shown by the USA and EU governments during the Uruguay Round agreement that was signed in 1994 so that in indirect ways, developing countries "rejected" the Doha multilateral trade liberalization agreement. The round was supposed to be finalized in 2005 but has instead lapsed a few times. The plan by rich countries led by the USA, to "control and administer economic policy and development in developing countries" through the Doha Round seemed to fall apart. So far there are no solid indications that the Doha Round of the WTO will materialize in the near future.

A second possible reason for US involvement in the TPPA is the potential to utilize TPPA as one solution for the country's economic recovery and as a plan for long-term economic growth $^{14}$. The impact of the financial crisis of 2007/2008 on the US economy is felt until today. The country's economic performance remains sluggish until the present. Real GDP growth hovered around 3 percent from 2008 to 2013. Even though unemployment rates have declined from 11 percent in 2009 to 8 percent in 2013, the labor market situation remains tight and sluggish. Budget deficits increased significantly every year and policy changes failed to generate market confidence. In addition, the current account of balance of payments is persistently in a deficit and has become a major headache to the government. The quantitative easing policy with a lower interest rates is also unable to stimulate private investment as an engine of economic recovery and growth. The future of the US economy seems to be bleak as competition in the global commodity market will be very competitive in the 21 st century. Developing countries including China may devalue their currencies as a way to stimulate and strengthen growth in the economy via the exports sector which would further hurt the US exports sector. Therefore, it is believed that the TPPA has considerable strategic economic significance to the US in searching for new markets and creating fresh growth opportunities through international trade ${ }^{15}$. Since Southeast Asia is speculated to become the new center of world economic growth in the $21^{\text {st }}$ century, the US via TPPA plans to grasp economic opportunities in Southeast Asia. Southeast Asia's intraregional trade as a share of total trade is far above that of any other developing region and is closer to that of high-income countries ${ }^{16}$. The region has overtaken NAFTA in terms of intraregional trade as a share of total trade of the region with the world and has been catching up with the European Union ${ }^{17}$. 
The large and growing markets of the Asia-Pacific region are already key destinations for US manufactured goods, agricultural products, and services suppliers, and the TPPA will further deepen this trade and investment. As a group, the TPPA countries are the largest goods and services export market for the United States. US exports of goods to the broader Asia-Pacific region totaled $\$ 942$ billion in 2012, representing 61 percent of total US goods exports. US exports of agricultural products to the region totaled $\$ 106$ billion in 2012,75 percent of total US agricultural exports ${ }^{18}$. Private services exports totaled $\$ 226$ billion in 2011, 38 percent of total US private services exports to the world. America's small and medium-sized enterprises alone exported $\$ 247$ billion to the Asia-Pacific region in $2011^{19}$.

The third possible reason is a threat of US Dollar (USD) role by the Chinese government move in internationalizing yuan in international economy, i.e promoting and increasing utilizing yuan in international transactions with her major economic partners. Since 2009 China has signed currency (RMB) bilateral swap agreements with 25 countries and the total amount of the swap arrangement was over 2.7 trillion yuan ${ }^{20}$. The main intention of the swap arrangement is to increase usage of yuan/Remimbi in international trade between China's partners. In other word, the arrangement is to reduce usage of US dollar (USD) between China and her trade partners in trading. In the case of bilateral agreement between China and Russia in Novemver 2010, both countries have abandoned using USD as the medium of exchange in bilateral trade, and using their own currencies in international payments. Regarding the matter and which may irk US government is the monetary cooperation between People Bank of China (PBOC) and European Central Bank (ECB) had establish bilateral agreement on currency swap arrangement on 9 October 2013. The swap line has a maximum size of 350 billion yuan or 45 billion euro. Related to the issue, on March 28, 2014, the PBOC and the Deutsche Bundesbank signed a memorandum of understanding in establishing a clearing and settlement arrangement of yuan payments in Frankfurt. Also, on March 31, 2014, the PBOC and Bank of England signed a memorandum of understanding regarding yuan clearing and settlement arrangements in London. If the usage of yuan in international economic increase the government may proceed to a full yuan convertibility, and this would challenge the role of USD in international economy.

Besides economic reasons as elaborated above I suspect that there are other motives for US participation in and leading the TPPA negotiation. The motives are unambiguously linked to security in the Asia-Pacific ${ }^{21}$ region and Southeast Asia with plans to contain China's economic and political power advancements in Southeast Asia. China's economy was growing rapidly at an average of 11 percent from 1990-2006 before falling to 8 percent from 2007-2013. The economy is expected to overtake the US economy by the end of 2016. Based on the real cost of living and purchasing power, the size of the Chinese economy in 2011 was $87 \%$ of the US economy, up from $43 \%$ in $2005^{22}$. This situation was predicted by the International Monetary Fund (IMF) in 2011 and that the US could lose its status as a larger economy within five years after $2011^{23}$. Chinese goods and investments have reached every corner of the world. The aggression of the Chinese government and investors for mineral and energy sources has increased competition for natural resources predominantly "controlled" by the US and other members of G-7. These developments seem to have escalated tensions for American policy makers with regard to maintaining future, sustainable sources of energy. The growing influence of China on the world economy has increased the level of uneasiness for US politicians and business communities.

China's total exports to the TPPA group in 2001 was approximately USD120.3 billion and imports from the members at about USD94.2 billion $^{24}$. This trade increased to USD730.2 billion and USD 555.2 billion in 2012 respectively. Compared to ASEAN + 3, total exports in 2012 was approximately USD444.2 billion and imports at about USD540.1 billion. For APEC in 2012, China - APEC intra-trade recorded exports was approximately USD130.6 billion and imports about USD1142.5 billion. In case of the US, total exports to TPPA members were lower than China. In 2012, US total exports to TPPA members were near USD688.8 billion while imports were about USD856.5. The US has a trade deficit with the TPPA members, in aggregate $^{25}$. Total exports to ASEAN+3 in 2012, was about USD298.5 billion while imports were 
near USD783.0 billion. Exports to APEC in 2012 was about USD941.6 billion and imports USD1493.7 billion, and the US faces trade deficits with APEC members, in aggregate ${ }^{26}$.

To contain China and not be isolated from Southeast Asia, the US government is aggressively pushing and promoting the TPPA in the region and at the same time strengthening political and economic relations with countries in Southeast Asia and with South Korea, Japan and other Pacific island countries. This is important: Creating a large economic or trade bloc could possibly hinder China's economic progression and political influence in the region. Close allies to the US government particularly Australia, New Zealand and Singapore have had good political and economic relations with countries in TPPA and also formed bilateral economic comprehensive partnerships with some TPPA countries. This is an added advantage to the US since the TPPA may have strong "backing" by the allies. The objective of the Obama administration to strengthen a closer engagement with Southeast Asia and Asia-Pacific countries would be easier since this effort would have strong support from America's close trade partners/allies. Therefore, there is an opportunity for the US government to increase its presence in Southeast Asia through TPPA. The US plans to make the TPPA as a main flagship of an American trade initiative in the region. In President Obama's Suntory Hall speech, he expressed that, "[the US] have a stake in the future of this region, because what happens here has a direct effect on our lives at home", and adding that, "as an Asia Pacific nation, the United States expects to be involved in the discussions that shape the future of this region and to participate fully in appropriate organizations as they are established and evolve" (Obama, 2011 27 quoted in Ming-Te and Tai-Ting $\mathrm{Liu}^{28}$ ).

The US government attempted to dictate to China's government on economic and political matters by pressuring for yuan revaluation in the early 2000s. Other members of G-7 particularly Japan also demanded that the Chinese government revalue the yuan ${ }^{29}$. The pressure for yuan revaluation started since the time of former President Bush Jr.'s administration. During the Bush period, Sino-US trade frictions and China bashing emerged. The government pressured the Chinese to correct the trade deficit so that American goods would be able to penetrate the Chinese market. The American government argued that cheap Chinese products in term of the US dollar had caused American goods unable to compete with Chinese goods in the world commodity market. There were too many "unpleasant voices and noises" from G-7 countries. So with the intention to preserve the export markets, in July 2005 the Chinese government de-pegged the yuan. However, the Chinese government still manages the exchange rate of the yuan against the dollar. Based on the USD/Yuan exchange rate trend, the Chinese government adopted a "crawling-pegged system". Since de-pegging, the yuan has appreciated and the appreciation of the yuan against the dollar is about $20 \%$. The move to "manage" China by making their goods expensive or less competitive via exchange rates in the world economy in fact has failed. Therefore which I believed the TPPA was adopted as a second measure by the US to isolate and discriminate against Chinese goods in Southeast Asia and limiting China's ascendency in economy performance, and also to diminish China political influence in the region.

\section{Chinese Government Response to US-led TPPA}

China has suspected that the US deliberately excluded them from joining the TPPA. If both countries were at the negotiation table, these two major powers may have prevented the conclusion of the agreement. I believe that the US does not want to have another "strong" country in the group, otherwise the US will be unable to maneuver or "control" the bloc, ensuring that US interests will be preserved. Most political economists see that the TPPA as a plan to reduce China's presence in Southeast Asia. In an article published in the People's Daily, an official newspaper of the Communist Party of China, a journalist, Ding Gang, states that "the U.S. does not want to be squeezed out of the Asia-Pacific region by China...(the) TPP is superficially an economic agreement but contains an obvious political purpose to constrain China's rise, ${ }^{\text {,30. }}$.

The Chinese government anticipated that there is actually "a conspiracy between the US and their allies, namely Japan, Australia, New Zealand and some members of ASEAN" to "kill" 
the East Asia Free Trade Area initiative that was proposed by the Chinese government in 1998, or to break-up ASEAN+3 and to dilute China's economic and political positions in Southeast Asia. President Obama's visit to countries in East Asia and Southeast Asia in early 2014 and in November 2010 have drawn attention as there were hidden discussions on issues pertinent to Southeast Asia and security in the South China Sea (SCS). President Obama's November 2010 trip to Asia was, "America"s opening move in a new great power game unfolding in Asia", as mentioned by Fareed Zakaria ${ }^{31}$. According to Zakaria, the President hopes that a closer relationship between Washington and Beijing could be used to moderate Beijing"s behavior. The president also proposed American engagement with China's Asian neighbors, in the case China's rise turns increasingly negative ${ }^{\$ 32}$. Between ASEAN and China, deriving a solution regarding economic benefits in the South China Sea and resolving sovereignty claims on particular islands including the Spratly Islands ${ }^{33}$ have reached a deadlock. Diplomatic channels have failed to calm political tensions among Southeast Asian countries and their claims of sovereignty over islands and territorities in the SCS while China remains stubborn in refusing to back off from its claims. The issue worsened when the Chinese government asserted its rights to regulate fishing across all reaches of the South China Sea ${ }^{34}$. In another occasion, in November 2013, the government announced an Air Defense Identification Zone over the East China Sea covering islands disputed with Japan ${ }^{35}$. The issue of the South China Sea including the Spratly Islands and other islands is the main obstacle for China in demonstrating a good neighbor policy Recently the Chinese government claimed that nearly all parts of the South China Sea belong to China. There have been occasions when the Chinese navy clashed with Philippine and Vietnamese marine and fisherman boats.

In November 2002 in Phnom Penh, Cambodia, members of ASEAN and China signed the Treaty of Amity of Friendship and Cooperation and the Declaration on the Conduct of Parties in the South China Sea (DOC) with the desire to promote peaceful, friendly and harmonious environment in the South China Sea. On July 21, 2011 in Bali, Indonesia, ASEAN and China adopted the Guidelines to implement the DOC. Although all parties signed a DOC to peacefully settle the dispute, so far it has failed to bring any successful solutions. China has not stepped back even an inch from its vast sovereignty claims over the SCS. This has become a flash point enabling outside powers to destabilize ASEAN-China relations ${ }^{36}$. The SCS issue suggests that the emergence of China is actually "dangerous" to stability and peace in Southeast Asia. ASEAN also fears that the South China Sea will become a battleground between China and the USA. They perceive the growing influence of China as a threat to regional peace. On the other hand, many members of ASEAN enjoy close relations and security cooperation with the US ${ }^{37}$. ASEAN members regard the US as a key offshore balancer ${ }^{38}$. Therefore, it would be less troublesome for the US government to preserve its interests in the South China Sea. The principal U.S. interest in Southeast Asia today lies in countering and ultimately moderating China's aggressive claims and behavior that threaten regional peace, security, and prosperity ${ }^{39}$.

As a kind of "insurance policy" or hedging against the negative impact or risk of the TPPA, China actively pursued other trade arrangements with its neighbors. The government engaged closer economic ties with Central Asia and Russia under the Shanghai Cooperation Organization $(\mathrm{SCO})^{40}$. Some believed that one of the original purposes of the SCO was to serve as a counter-balance to NATO and the United States and in particular to avoid conflicts that would allow the United States to intervene in areas bordering Russia and China. The SCO not only engaged in political and security matters but also enhanced a deep economic cooperation. The United States applied to be an observer in the SCO during the administration of George Bush Jr., but the application was rejected in 2006.

Another notable arrangement that the Chinese government is energetically involved in is the sub-regional development of the Greater Mekong Sub-Region (GMS) which was developed in 1992. The GMS is a regional economic cooperation mechansim within the Langcang-Mekong River Basin. The GMS covers the western part of China, Laos, Vietnema, Cambodia, Eastern and Northern part of Thailand and Myanmar. The Chinese government was seen as actively involved in the GMS. The GMS development has stimulated industrialization and urbanization of the 
region. Infrastructure development such as road and railroads were carried out extensively. Somehow the GMS has transformed the region into an economic and transportation corridor ${ }^{41}$. Two regions of China are involved in the GMS: Yunnan participated in 1992 and Guangxi in 2005. Yunnan total trade with GMS was about USD93.4 billions from 2005-2009 ${ }^{42}$. In 2013, the trade volume between China and GMS members about USD153.4 billion $^{43}$. The Chinese government via Yunnan has invested huge amounts of investments in various projects such as hydro-electricity, mineral exploration, electricity, processing trade, machinery and building materials. Seventy percent of these investments came from private enterprises. In 2013, Chinese have invested about USD2.3 billion in the region ${ }^{44}$. In 2009, China National Petroleum Cooperation (CNPC) received exclusive rights to build and operate China-Myanmar crude oil and gas pipelines.

Related to GMS, in May 2014 the Chinese government plans to begin building an economic corridor between the western part of China and Myanmar, Bangladesh, and the eastern and northeastern parts of India known as the BCIM corridor ${ }^{45}$. This proposed economic corridor covers about 1.65 million square kilometers. This region is a market of 2.8 billion people with a GDP of USD9.3 trillion in 2011. The BCIM corridor would be another region which will produce huge benefits to people and business communities of China. For this corridor development the Chinese government has proposed 20 projects worth about USD53.87 billions. The projects involve highways, airports, hydropower and wind power stations in the western region including Sichuan, Yunnan, Xinjiang and Tibet ${ }^{46}$. The Chinese government has increased closer economic relations with countries in Africa and Latin America. China trade and investment to those countries have increased significantly. China has become a major trade partner for African countries. Trade between the two regions was over USD100 billion during the 2000s. African natural resources particularly crude oil represents an attraction for Chinese investors. China imports 30 percent of its crude oil from Africa compared to the US that imports about 15 percent from Africa ${ }^{47}$.

Besides the above reasons, the Chinese government has started to focus on buidling up a strong diplomatic and economic relationship with her neighbours i.e Central Asia countries. In 1997 the Central Asian Regional Economic Cooperation (CAREC) was created. CAREC was proposed by Asian Development Bank (ADB) to encourage economic cooperation among countries in Central Asia. Most countries of Central Asia are land-locked, located strategically and have a solid connectivity. Surprisingly, CAREC includes only the China as a global trade actor for the region. As of 2013, 146 CAREC-related projects worth around $\$ 22.4$ billion have been implemented in the four core areas of cooperation - transport, trade facilitation, trade policy, and energy ${ }^{48}$. China actually has became one of the economic forces in Central Asia, with trade between China and the five Central Asian states rising from \$527 million per year in 1992 to \$30 billion annually by $2010^{49}$. China seems is turning to Central Asia. In a policy paper by Wang $\mathrm{Jisi}^{50}$ which was presented in October 2012, encouraged the Chinese government to "march westwards". As American government expanding their influence in the Far East, Wang suggested that Chinese policymakers should focus on developing China's economic and diplomatic relationships with its Western neighbours, i.e Central Asia ${ }^{51}$. This is because cooperation and competition have not established yet in the region significantly ${ }^{52}$. This actually a golden opportunity to Chinese leaders to solidify its international presence in Central Asia. This region should be a bigger target for Chinese government and investors to integrate the region firmly and as a bold strategy to ensure China presence and its relevance, and to shrug off American influence in the region considerably.

Another surprise move was made by the Chinese government in retaliation and response to the US-led TPPA of April 30, 2014. China plans to explore the possibility of the development of the Asia-Pacific Free Trade Area (FTAAP) at the APEC meeting in late 2014. This move is a strategic counter to the US-led TPPA. Instead of focusing on the Regional Comprehensive Economic Partnership (RCEP) (to be discussed in a subsequent sub-section), China may be looking at the FTAAP as its other tool to mitigate adverse impacts arising from the TPPA toward China. FTAAP is the larger economic bloc that encompasses all 21 APEC members. Therefore, 
pushing the proposal will not just complement the TPPA but also absorb the 12 member TPPA within the larger free trade bloc. At the APEC summit at Beijing on 11 November 2014, the members of the group agreed with China's proposal establishing the FTAAP. This develepment indicates that China now effectively in the driver's seat, seizing the global free trade initiative away from the US and breaking the TPPA.

The TPPA was seen as the most credible pathway to broader Asia-Pacific regional economic integration. A statement was made by Dr Craig Emerson, Minister for Trade and Competitiveness of Australia at the APEC MRT Meeting on $4^{\text {th }}$ June $2012^{53}$. "One way of getting to regional economic integration through APEC is a Free Trade Area of the Asia Pacific. The concept is a very good one and it has been endorsed time and time again by leaders of the APEC economies. And the vehicle indeed for getting to the Free Trade of Asia Pacific can be the TransPacific Partnership which does in fact constitute nine economies that are all members of APEC and three others that are signaling a keen interest in the idea of joining the TPPA ${ }^{54}$.

However since the move made by Chinese to pursue FTAAP, which I believe as a countering strategy to TPPA-led by The US, and to ensure that China interests in Southeast Asia is preserved, so the TPPA seem to be no longer as a pathfinder to FTAAP. Chinese now on driver seat to navigate the possibility of FTAAP development. Therefore the American government wants the TPPA to grow into a regional FTA covering the 21 APEC countries seem to fall apart. Moreover, the FTAAP proposal also will mean that the RCEP is firmly established as the other cornerstone of the country's free trade policy ${ }^{55}$ with ASEAN losing its grip on the RCEP, meaning losing its place in leading the RCEP. The proposal of a possible development of FTAAP indirectly indicates China's aspiration for a global role and to install the country's position firmly as one of the world's economic powers.

\section{China, ASEAN and RCEP}

The "Asia-centric" approach differs from the US-led TPPA negotiations in terms of its nonbinding and voluntary approach as opposed to the strict and binding track of the TPPA. The TPPA actually has a pronounced "non-Asian" flavor to economic integration efforts in Asia. For several economies negotiating the framework of the TPPA common to other "Asia-centric" negotiation frameworks as well, the challenges of complying with the two different approaches and their demands can be daunting. The idea of the RCEP was to reconcile the two long-standing proposals into a large region-wide trade agreement, i.e., the East Asian Free Trade Agreement (EAFTA) that included ASEAN, China, Japan and South Korea and the Comprehensive Economic Partnership (CEP) comprised of Australia, India and New Zealand. The RCEP will establish a deeper economic cooperation than the existing FTA agreements. The RCEP was suggested by ASEAN at the ASEAN leaders summit in Bali, Indonesia in November 2011. At the East Asia Summit on November 20, 2012 in Cambodia, the leaders of the 16 participating countries endorsed and launched the RCEP framework. In May 2013, participating countries began the negotiations and are scheduled to conclude by the end of 2015.

Since the early 1990s, ASEAN in fact occupies a core position in the economic integration of Southeast Asia. Actually ASEAN was the main architecture and a driving force in integrating all countries in Southeast Asia into a form of bilateral economic partnership, i.e., free trade area. With the development of the East Asia Economic Caucus (EAEC), ASEAN+3 and the East Asia Summit initiated by ASEAN it is believed that the RCEP would expand ASEAN's role and centrality in Southeast Asia. However, ASEAN's centrality is challenged by many new and overlapping economic cooperation arrangements in the region including the TPPA. ASEAN aims to preserve its centrality to economic co-operation within Southeast and East Asia. If ASEAN does not respond effectively to potential competition between the TPPA and RCEP, ASEAN's role as a driving force in the various regional arrangements in the future is likely to decline. Another potential factor that could reduce ASEAN's role and relevance in Southeast Asia is the 
rivalry between the US and China in the region. Some people have argued that ASEAN would most likely be able to take the helm of the region because the RCEP was put forward to avoid Japan and China fighting for controlling regionalism in Southeast Asia. Since most members of RCEP exhibit stable economic growth the RCEP seems to be attractive to Japan and China.

Prior to the RCEP development, Japan and South Korea favored and suggested ASEAN plus 6 other countries (China, Japan, South Korea, India, Australia and New Zealand). However, China initially wanted to have ASEAN plus 3 (China, Japan and South Korea) included in the pact. However a counter proposal from the American-led TPPA in which China is excluded, may have changed China's intention toward ASEAN+ 6 so that the RCEP was warmly accepted by the Chinese government.

The RCEP and TPPA are multi-track and multi-speed arrangements that will alter and reshape regionalism in Southeast Asia. The TPPA and RCEP seem to have become rivals to each other in the present and in the near future. The RCEP group has a total population of over 3 billion people representing 49 per cent of the world's population. Based on 2012 data, the RCEP has a combined GDP of about \$21 trillion, roughly accounting for 30 percent of world total GDP, and a trade share estimated at around 27 per cent of global trade. Trade share within the region is about 44.12 percent and makes up 26 per cent of the world's FDI inflows. The huge trade is directly linked to three of the largest economies in the world, China, India and Japan. The RCEP would create the world's largest trading bloc compared to the TPPA. In the case of the TPPA, the total population of the group is about 800 million. Based on 2012 data, the TPPA group share of global GDP is approximately 38.2 percent, trade share within the region about 41.6 percent, and trade share near 22 percent of global trade. Based on these figures, the RCEP appears to be more promising than the TPPA.

Therefore, competition to dominate the region would seem to be between the ASEAN-led RCEP and the US-led Trans-Pacific Partnership (TPPA). Even though the RCEP and TPPA have quite similar objectives such as trade liberalization and economic integration, the RCEP is less ambitious than the TPPA. The ASEAN-led RCEP is a more 'Asian approach' of gradual trade liberalization. The US-led TPP is quite aggressive and plans for deeper economic integration than the RCEP. The TPPA covers not only those issues included in a regular FTA, but also includes provisions for non-economic issues as elaborated in the previous sub-section so that it will be difficult for developing countries to agree on. In contrast, the RCEP offers flexibility, for example, allowing for decisions to be made through any agreed modality and enabling special and differential treatment of ASEAN members enabling a more generous consideration of each nation-state's needs. The RCEP appears to be more inclusive and flexible as it was designed to cater to diverse circumstances and development gaps within ASEAN and between ASEAN and its FTA partners. The two agreements are quite different in their approach, process and potentially quite different in outcomes. The TPPA has completed 21 rounds of negotiations while the RCEP is still in its early stages ${ }^{56}$ with the sudden rise of the RCEP due to many concerns in Asia has about the TPPA.

In line with its pivot toward Asia, the US has led the expansion of membership of the TPPA and the government has encouraged other APEC countries to join the group. The rationale for expanding the membership of the TPPA is to meet economic challenges that the US would face in the 21st century. Additionally, if more countries join the TPPA this would mean that the US role in Asia Pacific and Southeast Asia is acknowledged and would eventually marginalize China in these regions. The US-led TPPA and ASEAN-led RCEP may fall into conflict. Competition between the two groups has the potential to divide ASEAN members and Southeast Asian countries. China and India are not presently part of the TPPA negotiations. If both of these economies joined RCEP (both countries are already in the group), their membership could build a new configuration game in Southeast Asia and pose a challenge to the TPPA. The TPPA and RCEP are game-changers in regional economic governance and architecture. There is political tension between the US and China where each country wants to shape economic cooperation in Southeast Asia in order to secure each of its economic interests. Consequently, rivalry between 
these two countries might become the predominant factor in how the regional economic architecture will be developed as an entirety encompassing Southeast Asia.

Some ASEAN members were concerned that if some of them joined the TPPA this could possibly create disharmony among their political and economic ties. Since the US is aggressively pushing the TPPA among APEC members, ASEAN countries realize that its role in economic integration in Southeast Asia maybe be weakened if the TPPA materializes and is able to attract other countries into joining the group. A fear is that the US will eventually remove ASEAN leadership or marginalize the leadership's role in the region. The US has meanwhile succeeded in strengthening economic and political ties with a number of ASEAN members since Obama became President. Therefore, the US rebalancing strategy may produce an impact on the centrality of ASEAN in regional cooperation. Furthermore, the TPPA could be used to rebalance Asia against China's rising influence. The American media has suggested that the TPPA is being used to counteract China's economic influence in the region. President Obama clearly stated in his election campaign that he would promote the TPPA in order to pressure China into adhering to international trade rules and international law.

I suspects that the US attempt to re-balance its strategy in the Asia-Pacfic region has motivated ASEAN into forming a new framework of cooperation and speeding the realization of ASEAN+6 or plans for the EAFTA in which this framework would maintain ASEAN relevance in Southeast Asia. Therefore, the author believes that the development of the RCEP will stand against the TPPA. The RCEP hopes to slow down the process of the US-led TPPA or even destroy it altogether. China is an important driving force for achieving the RCEP. China always respects and supports the leading role of ASEAN in regional cooperation. At the same time, China is concerned about the TPPA that excludes its participation in negotiations. Up to now the nature of the TPPA is still ambiguous and is presumed to be part of the US program to contain China. Therefore, it is obvious that China supports RCEP in reaction to the potential risks.

\section{Conclusion}

One of biggest questions in regional economic integration development in Southeast Asia is the role of China and how Japan and its allies confront the emergence of Chinese power in the region. Japan is more concerned with monetary matters or trade gain rather than building coherent and sustainable relationships with other countries in Asia including members of ASEAN. Since China has established economic linkages with ASEAN and has become the third largest trade partner to the organization, this has produced concerns for the US and Japan and their close allies. The US and Japan are worried about the growing economic and political influence of China in Southeast Asia. Therefore they plan to block realization of the Chinese government's vision to become the leader in regionalism and economic development in Southeast Asia. The Obama administration committed that the US would safeguard US and US allies' interests in Asia-Pacific and in Southeast Asia. One solution is the US joining and leading the TPPA since December 2009. Through the TPPA, the US is attempting to avoid any marginalization in trade and market access in the region. China will be affected economically and politically by the US-led TPPA. As a hedging strategy to US involvement in Southeast Asia and Asia Pacific via the TPPA, China has promptly developed new economic engagements with neighbor countries in South Asia and Central Asia. However, the issues around the South China Sea may derail China's effort in maintaining pleasant economic and political ties with members of ASEAN developed since the early 1990s. If the relationship between China and ASEAN is heading toward political tension, we may see the US leading the Southeast Asia and Asia Pacific regions, sidelining China and ASEAN.

As for the TPPA, is expected to develop a level playing field for businesses in the Asia and Pacific region. However, the group's members have different levels of economic development. Issues that are covered under the TPPA will require significant reforms in domestic industrial and 
economic policies for most of the members. These may raise challenges for developing countries that need economic reforms and for economies that have state-owned enterprises. While it is possible that the RCEP and TPPA may generate competition between the two trade arrangements, both are potential pathways to a free trade area of the Asia and Pacific region (FTAAP).

The US-led TPPA may cause serious implications to ASEAN's role in integrating countries in Southeast Asia. ASEAN has signed comprehensive trade liberalization packages with non-ASEAN members such as China, Japan, South Korea, Australia, New Zealand and India. Whether the approach is ASEAN+3 or ASEAN+6 is feasible, the main argument in this article is that the TPPA will complicate matters between governments by liberalizing trade under the existing free trade agreement. Furthermore the TPPA is not an "ordinary" FTA agreement. It is a mini-multilateral trade liberalization which covers not only market access, but a number of critical subjects negotiated under the Doha round and brought into the TPPA. If TPPA is finalized it will undermine the effectiveness of ASEAN in developing fair and equitable trade liberalization.

\section{Notes}

1. The Asian financial crisis affected the countries of Malaysia, Indonesia, Thailand and South Korea The Chinese government maintained the current exchange rate between the Chinese yuan and US dollar, so the affected countries were able to recover from the crisis through trade channels. This suggests that China played a role in helping its neighbour when needed (Jiang,2010). On the other hand, the US government seemed to not be as helpful, by indirectly providing a "painful help" such as the use of structural adjustment packages via the IMF

2. Shaun Breslin, 'Supplying Demand or Demanding Supply? An Alternative Look at the Forces Driving East Asian Community Building', Stanley Foundation Policy Analysis Brief, Stanley Foundation, Washington D.C., (November 2007). Available at http://www.stanleyfoundation.org/resources.cfm?id=268 Shaun Breslin, 'China and the global order: signalling threat or friendship?' International Affairs, Volume 89 (Number 3) (2013). pp. 615-634. David L. Shambaugh, 'China engages Asia: reshaping the regional order', International Security 29(3) (2005): 64-99

3. Other parts of the world such as Latin America, Africa, West Asia and Middle East and their economic picture lag behind the economic performance of countries in Southeast Asia

4. The P4-TTP agreement is a comprehensive agreement. The agreement comprises 20 chapters that cover areas such as trade in goods, tariffication, services sector liberalization, intellectual property, investment liberalization, government procurement, competition policy and disputes settlement

5. Mohamed Aslam, 'Trans-Pacific Partnership Agreement. A Possible Impact on Malaysia Economy', Seminar Trans- Pacific Partnership Agreement as a Tool of Development and Economic Growth in Malaysia, Faculty of Economics and Management, Universiti Pendidikan Sultan Idris, Tanjung Malim, Perak, (18 September 2013). World Trade Organization (WTO), 'Factual presentation: Trans-Pacific Strategic Economic Partnership Agreement between Brunei Darrussalam, Chile, New Zealand and Singapore (goods and services)', Report by the Secretariat, WT/REG229/1, (9 May 2008).

6. Ian F Fergusson and Bruce Vaughn, 'The Trans-pacific Startegic Economic Partnership Agreement', Congressional Research Service, Paper No. R40502, Washington DC, (December, 2009), page 4.

7. Ian F Fergusson and Bruce Vaughn, 'The Trans-pacific Startegic Economic Partnership Agreement' page 4

8. Ian F Fergusson and Bruce Vaughn, 'The Trans-pacific Startegic Economic Partnership Agreement' page 1

9. Ann Capling and John Ravenhill, 'Multilateralising regionalism: what role for the Trans-Pacific Partnership Agreement?', The Pacific Review, 24:5 (2011), 553-575

10. Tan Seng Chye. 'Changing Global Landscape and Enhanced US Engagement with Asia-Challenges and Emerging Trend', Asia-Pacific Review, 19:1, (2012) 108-129

11. Some people label TPPA a "second NAFTA".

12. Proposed by the US and EU after Uruguay Round signed in April 1994 at Marrakesh

13. Wen Jin Yuan, The Trans-Pacific Partnership and China's Corresponding Strategies, A Freeman Briefing Report, (June,(2012), Washington DC

14. It seems that the TPPA is a 'second-best' solution to the Doha Round of WTO for long-term economic growth 
15. Amitendu Palit, The Trans-Pacific Strategic Economic Partnership. Will it divide the Asia-Pacific? Breifing Paper, No. 6/2012, (CUTS Centre for International Trade, Economics \& Environment, Jaipur, India, 2012)

16. Hamid Alavi, Ralph Van Doorn and Vikram Nehru, 'Building a Neighbourhodd - One Policy at a Time: The case for deeper economic integration in East Asia', in Takashi Shiraishi and Jiro Okamoto, (eds) Engaging East Asian Integration, (IDE-JETRO and ISEAS, Singapore 2012), page 46-96

17. Hamid Alavi, Ralph Van Doorn and Vikram Nehru, 'Building a Neighbourhodd - One Policy at a Time: The case for deeper economic integration in East Asia'

18. Mohamed Aslam, Trans-Pacific Partnership Agreement. A Possible Impact on Malaysia Economy, Seminar Trans- Pacific Partnership Agreement as a Tool of Development and Economic Growth in Malaysia, Faculty of Economics and Management, Universiti Pendidikan Sultan Idris, Tanjung Malim, Perak, 18 September (2013).

19. Mohamed Aslam, Trans-Pacific Partnership Agreement. A Possible Impact on Malaysia Economy

20. Information on yuan swap arrangements were collected from the People Bank of China

21. For instance North Korea militirization and nuclearization, Sino-Japan clashes on Senkaku Island, ASEAN-China disagreement on China maritime boundaries in South China Sea and Chinese claims for a number of slands including the Spratly Islands

22. Angela Monaghan, 'China poised to overtake US as world's largest economy, research shows', The Guardian, 30 April (2014). http://www.theguardian.com/business/2014/apr/30/china-overtake-us-worldslargest-economy?INTCMP=ILCNETTXT3487, accessed 8 May 2014

23. Gardner, David Gardner, 'The Age of America ends in 2016: IMF predicts the year China's economy will surpass US', The Dailymail, (April 26, 2011). http://www.dailymail.co.uk/news/article-1380486/TheAge-America-ends-2016-IMF-predicts-year-Chinas-economy-surpass-US.html\#ixzz317AuW3K3, accessed on 8 May2014

24. Mohamed Aslam, Trans-Pacific Partnership Agreement. A Possible Impact on Malaysia Economy, Seminar Trans- Pacific Partnership Agreement as a Tool of Development and Economic Growth in Malaysia, Faculty of Economics and Management, Universiti Pendidikan Sultan Idris, Tanjung Malim, Perak, 18 September (2013)

25. Mohamed Aslam, The US-led Trans-Pacific Partnership Agreement: Implication on ASEAN and China in East Asian Regionalism, $7^{\text {th }}$ ACAS International Conference, Asian Integration: History, Contemporary Integrative Efforts, Implications of State Formation and Reconfiguration. Ateneo de Manila University, Manila, Philippines, 18 July (2014).

26. Mohamed Aslam, The US-led Trans-Pacific Partnership Agreement: Implication on ASEAN and China in East Asian Regionalism

27. President Barack Obama at Suntory Hall, “ http://www.whitehouse.gov/the-press-office/remarkspresident-barack-obama-suntory-hall

28. Hung Ming-Te and Tony Tai-Ting Liu, 'The Trans-Pacific Strategic Economic Partnership and Its Implications for China's Role in East Asia Regional Integration', Journal of Contemporary Eastern Asia, 11(2) (2012): 1-12

29. The US Senate and the administration of former President Bush Jr. administration pressured Beijing for an exchange rate adjustment since 2005. In April 2005, the Senate voted 67-33 in favor of considering legislation threatening Beijing with a $27.5 \%$ tariff on all US imports from China unless the yuan is allowed to float. Also the government wanted to use the 1988 Trade Act to punish countries that manipulate their exchange rates in order to gain a competitive advantage. China was named as a currency manipulator by the US Treasury in 1994 in response to Beijing's devaluation of the yuan in that year. Since the 1994 devaluation, the yuan has traded in a narrow band against the dollar. Bilateral talks have failed to produce any changes in China's currency regime in the past 11 years

30. Wen Jin Yuan, The Trans-Pacific Partnership and China's Corresponding Strategies

31. Fareed Zakaria, 'A Hedge Strategy Toward China', The Washington Post, (15 November (2012).

32. Fareed Zakaria, 'A Hedge Strategy Toward China'

33. Beijing claims sovereign rights to almost the entirety of the South China Sea, quoted in The Sun, 'Sea row dominated ASEAN summit', (May 12, 2014). In January 2014, all foreign fishing vessels asked to apply for permission before entring a vast swath of the South China Sea

34. ASEAN foreign ministers expressed serious concerns as to what is going on in the South China Sea. This South China Sea continues to be a litmus test for ASEAN, quoted in The Sun, 'Sea row dominated ASEAN summit', (May 12, 2014). 
35. Another worrying concern is that President Xi Jinping continues to upgrade and expand China's maritime power to safeguard its claims to the South China Sea and East South China Sea. This has increased fear among members of ASEAN including South Korea and Japan. The current move by Xi Jinping is to face the US pivot to Asia Pacific and East Asia and as a warning to the US to not interfere in the seas, quoted in Suk Joon Yoon, 'Chinese version of the Monroe Doctrine', Focus Malaysia, (June 1420, 2014), page 58 .

| 66 36. Ronaque Ali Behan and Mughees Ahmed, 'China-ASEAN Relations: Implications for U.S. Interests', Asia Pacific Research Journal of Far East \& South East Asia, vol. 31 (2013): pp:157-165.

37. In Singapore, the US has deployed four ships, while in the Philippines the US rotates 500 personnel as part of a new cooperation with Manila. It will also rotate 2,500 marines in Darwin, see Yohanna Ririhena, 'US pivot creates volatility in Southeast Asia', The Jakarta Post, (June 21, 2013). Retrieved from http://www.thejakartapost.com/news/2013/06/21/us-pivot-creates-volatility-southeast-asia.html

38. Ian Storey, The United States and ASEAN-China Relations: All Quiet on the Southeast Asian Front, (The Strategic Studies Institute, Pennsylvania , October , 2007). Retrieved from http://www.strategicstudiesinstitute.army.mil/pubs/summary.cfm? $q=812$

39. Walter Lohman, America's Inadequate ASEAN Approach. September (2013), Retrieved from http://nationalinterest.org/commentary/americas-inadequate-asean-approach-9050?page =1

40. The organization, originally called the Shanghai Five, formed in 1996 largely to demilitarize the border between China and the former Soviet Union. In 2001, the organization added Uzbekistan and renamed itself the Shanghai Cooperation Organization. Mongolia received observer status in 2004. Iran, Pakistan, and India became observers the following year. The Shanghai Cooperation Organization (SCO) is an intergovernmental international organization founded in Shanghai on 15 June 2001 by six countries: China, Russia, Kazakhstan, Kyrgyzstan, Tajikistan and Uzbekistan.

41. Shresta, L Omkar and Aekapol Chongvilaivan, 'Greater Mekong Subregion: From Geographical Corridors to Socio-economic Corridors', in Omkar L. Shresta, and Aekapol Chongvilaivan (eds), Greater mekong Subregion. From Geographical to Socio-economic Integration, (Institute of Southeast Asian Studies Singapore, 2013), pp 1-17.

42. Guangsheng Lu, 'China (Yunnan) - GMS Economic Cooperation: New Development and New Problems', in Omkar L. Shresta, and Aekapol Chongvilaivan (eds), Greater mekong Subregion. From Geographical to Socio-economic Integration, (Institute of Southeast Asian Studies, Singapore, 2013), pp 103-118.

43. Zhao Yanrong,'Growing together in the Mekong', China Daily-Asia Weekly, (December 19-25, 2014) page 11.

44. Zhao Yanrong, 'Growing together in the Mekong'

45. The proposal of BCIM emerged at the Boao Forum for Asia which was held in China, Hainan province in April 2014.

46. John Emanuel, 'Upgrading corridor of connectivity', China Daily-Asia Weekly, (May 30 - June 5, 2014) page 7 .

47. Majid Ali Noonari,. 'Chinese Involvement in Africa and Its Impact on United States', Asia Pacific Research Journal of Far East \& South East Asia, vol. 31 (2013): 97-115.

48. Refer to http://www.carecprogram.org for further detail.

49. Refer to http://www.carecprogram.org for further detail.

50. Quoted in Emily Feng, "Marching West: Regional Integration in Central Asia", China Hands Journal, Vol.2 (2014), Issue I, http://www.chinahandsmagazine.com/politics--diplomacy/marching-west-regionalintegration-in-central-asia.

51. Emily Feng, "Marching West: Regional Integration in Central Asia", China Hands Journal, Vol.2 (2014).

52. Emily Feng, "Marching West: Regional Integration in Central Asia", China Hands Journal, Vol.2 (2014).

53. Craig Emerson,. APEC Ministers Responsible for Trade Meeting — Session Two: Priorities for APEC 2012, Speech at APEC 2012 Ministerial Meeting at Kazan Russia, (2012). http://trademinister.gov.au/speeches/Pages/2012/ce_sp_120604a.aspx?ministerid=2.

54. The "three others" here refer to Japan, Canada and Mexico

55. Karl Lee, 'Making sense of China's Asia-Pacific FTA agenda', The Sun, (5 May 2014).

56. The second-round of RCEP negotiations was held in September 2014 in Brisbane, Australia. 